\title{
Tooth Structure and Replacement of the Triassic Keichousaurus (Sauropterygia, Reptilia) From South China
}

\author{
Jun-ling Liao ${ }^{1,2}$, Tian Lan ${ }^{1 *}$, Guang-hui X ${ }^{3,4}$, Ji Li ${ }^{1}$, Yan-jiao Qin ${ }^{5}$, Ming-sheng Zhao ${ }^{6}$, \\ Yu-lan $\mathrm{Li}^{1}$ and Yue Wang ${ }^{1 *}$ \\ ${ }^{1}$ College of Resource and Environmental Engineering, Key Laboratory of Karst Georesources and Environment, Ministry of \\ Education, Guizhou University, Guiyang, China, ${ }^{2}$ College of Economics and Management, Xingyi Normal University for \\ Nationalities, Xingyi, China, ${ }^{3}$ Key Laboratory of Vertebrate Evolution and Human Origins of Chinese Academy of Sciences, \\ Institute of Vertebrate Paleontology and Paleoanthropology, Chinese Academy of Sciences, Beijing, China, ${ }^{4}$ CAS Center for \\ Excellence in Life and Paleoenvironment, Beijing, China, ${ }^{5}$ Research Department of Science and Technology, Guizhou \\ Geological Museum, Guiyang, China, ${ }^{6}$ College of Paleontology, Shenyang Normal University, Shenyang, China
}

\section{OPEN ACCESS}

Edited by: Pedro Martinez,

University of Barcelona, Spain

Reviewed by:

Mark Joseph MacDougall, Museum of Natural History Berlin

(MfN), Germany

Domenic D'Amore,

Daemen College, United States

*Correspondence:

Tian Lan

lantianing@sina.com

Yue Wang

gzyuewang@126.com

Specialty section:

This article was submitted to Evolutionary Developmental Biology,

a section of the journal

Frontiers in Ecology and Evolution

Received: 15 July 2021 Accepted: 05 November 2021 Published: 09 December 2021

Citation:

Liao JL, Lan T, Xu GH, Li J, Qin YJ, Zhao MS, Li YL and Wang Y (2021) Tooth Structure and Replacement of the Triassic Keichousaurus (Sauropterygia, Reptilia) From South China. Front. Ecol. Evol. 9:741851.

doi: 10.3389/fevo.2021.741851
The small-sized sauropterygian Keichousaurus hui was one of the most abundant marine reptiles from the Triassic Yangtze Sea in South China. Although Keichousaurus has been studied in many aspects, including the osteology, ontogeny, sexual dimorphism, and reproduction, the dentition of this marine reptile was only briefly described in external morphology. In this study, we provide new information on Keichousaurus tooth implantation, histology, and replacement based on a detailed examination of well-preserved specimens collected in the past decades. The tooth histology has been investigated for the first time by analyzing cross-sections of premaxillary teeth and the tooth attachment and implantation have been further revealed by $\mathrm{X}$-ray computed microtomography. We refer the tooth replacement of Keichousaurus to the iguanid replacement type on the basis of the observed invasion of small replacement tooth into the pulp cavity of the functional tooth. Given the resemblance to other extinct and modern piscivorous predators in the morphology and structure of teeth, Keichousaurus might mainly feed on small or juvenile fishes and some relatively soft-bodied invertebrates (e.g., mysidacean shrimps) from the same ecosystem.

Keywords: pulp cavity, plicidentine, tooth replacement, Keichousaurus, Triassic, South China

\section{INTRODUCTION}

Teeth are complex mineralized tissues that originated in jawed vertebrates more than 400 million years ago (Rücklin et al., 2012). The shape, implantation, and replacement of teeth differ widely across vertebrates and promote the radiation of this clade (Owen, 1841, 1842; Edmund, 1960, 1962; Peyer, 1968; Mehler and Bennett, 2003; Maxwell et al., 2012; Buchtová et al., 2013; LeBlanc et al., 2017; McCurry et al., 2019). Reptiles show a diverse array of tooth shapes from homodont to heterodont (Peyer, 1968; Rieppel, 2002) and from simple unicuspid to complex multicuspid teeth (Ungar, 2010; Handrigan and Richman, 2011), reflecting functional adaptation to various diets. Additionally, reptiles exhibit numerous combinations of tooth implantation and attachment (Peyer, 1968; Mehler and Bennett, 2003; Buchtová et al., 2013; LeBlanc et al., 2017), ranging from teeth possessing roots and lying within a socket (thecodonty), to teeth lying against the lingual wall 
of the jawbone (pleurodonty), and to teeth without roots or sockets that are attached to the apex of the marginal jawbones (acrodonty). Continuous tooth replacement (polyphyodonty) is common for the vast majority of reptiles, although some groups (e.g., acrodont lepidosaurs) have lost the ability to replace their dentition (monophyodonty) (Edmund, 1960, 1962; Peyer, 1968; Motani, 1997; Rieppel, 2001; Fastnacht, 2008; Maxwell et al., 2012; Buchtová et al., 2013; Neenan et al., 2014; LeBlanc and Reisz, 2015).

The small-sized sauropterygian Keichousaurus hui (rarely exceeding $50 \mathrm{~cm}$ in total length) is one of the most abundant reptiles from the Triassic Yangtze Sea in South China (Young, 1958; Rieppel and Lin, 1995; Jiang, 2002; Holmes et al., 2008; Cheng et al., 2009; Fu et al., 2013; Xue et al., 2013). The genus was originally classified by Young (1958) in Pachypleurosauridae or in its own family (Keichousauridae) (Young, 1965) before formal phylogenetic analyses. Recent analyses of the sauropterygian phylogeny place Keichousaurus either at a relative basal position of the Eosauropterygia (Shang et al., 2020) or within Pachypleurosauridae ( $\mathrm{Li}$ and Liu, 2020; Lin et al., 2021). Represented by large quantities of well-preserved specimens, Keichousaurus has been studied in many aspects including the ontogeny, taphonomy, reproduction, sexual dimorphism, allometry, and living style (Lin and Rieppel, 1998; Cheng et al., 2004, 2009; Holmes et al., 2008; Fu et al., 2013; Xue et al., 2013; Motani et al., 2015). However, the teeth of Keichousaurussignificant organs for taxonomy and ethology (Radinsky, 1961; Handrigan and Richman, 2011; Hwang, 2011) —were only briefly described in their external morphology (Young, 1958, 1965; Lin and Rieppel, 1998; Jiang, 2002; Holmes et al., 2008; Fu et al., 2013). Compared with those in other marine reptiles (Maisch and Matzke, 1997; Motani, 1997; Rieppel, 2001; Ciampaglio et al., 2005; Caldwell, 2007; Maxwell et al., 2012; Neenan et al., 2014; Sassoon et al., 2015), the teeth of Keichousaurus remain poorly known in their internal structure, function, and replacement.

In this study, through a detailed examination of wellpreserved specimens, we aim to describe the tooth morphology, internal structure, and tooth histology of Keichousaurus and to discuss the tooth replacement, dental function, and food preference of this taxon.

\section{MATERIALS AND METHODS}

All the studied specimens of Keichousaurus are housed in the Resource and Environmental Engineering College of Guizhou University (GZU), China. They were collected from the lower part of the Zhuganpo (lower) member of the Falang Formation in southwestern Guizhou (Dingxiao) and eastern Yunnan (Fuyuan), South China (Figure 1B). This member of fossil beds, composed of dark gray thin-to medium-bedded limestones or muddy limestones with dolomitic limestones, indicates a carbonate platform deposit environment (Liu and Xu, 1994; Wang, 1996, 2002; Rieppel, 1999; Rieppel et al., 2000; Jiang, 2002) (Figure 1A). Also, from the fossil beds, rich invertebrates, bony fishes, and several other types of marine reptiles are also found; the whole fossil assemblage represents the renowned Xingyi Biota ( $\mathrm{Su}$,
1959; Jin, 2001; Liu et al., 2002, 2003; Li, 2006; Geng and Jin, 2009; Xu et al., 2012, 2015, 2018a,b; Tintori et al., 2015; Sun et al., 2016; Ni et al., 2017; Xu and Ma, 2018; Shang et al., 2020; Xu, 2020). The age of this biota was controversial (Benton et al., 2013). Biostratigraphical studies of marine reptiles and ammonites (Young, 1958; Chen, 1985; Li, 2006; Zou et al., 2015) consistently support a late Middle Triassic (late Ladinian), but conodont biostratigraphy (Yang et al., 1995; Wang, 1996, 2002; Wang et al., 1998) suggests a younger Late Triassic (Carnian) age for this biota. Zou et al. (2015) commented that the previous conodont identification is inaccurate; the conodont "Paragondolella polygnathiformis" identified by Wang et al. (1998) is actually a transition Paragondolella polygnathiformis-P. nodosa recovered from a sample $3 \mathrm{~m}$ above the vertebrate-bearing interval. A recent zircon $\mathrm{U}-\mathrm{Pb}$ age dating $(240.8 \pm 1.8 \mathrm{Ma})(\mathrm{Li}$ et al., 2016) supports the determination of late Middle Triassic (Ladinian) for the Xingyi Biota.

The specimens were prepared mechanically with sharp steel needles and air scribe under optical microscope and some were washed by dilute oxalic acid to further remove the matrix. Tooth section and photography were performed at the Key Laboratory of Vertebrate Evolution and Human Origins of Chinese Academy of Sciences, Beijing, China. The whole skull of the specimen (GZU V0056) was removed and embedded in resin for preparation of transverse sections. Thin sections of four premaxillary teeth (about $30 \mu \mathrm{m}$ in thickness) were obtained from the bases of tooth crowns (perpendicular or nearly perpendicular to the long axis of the tooth). These sections were analyzed and photographed under cross-polarized light using the Zeiss Imager A2m microscope. X-ray computed microtomography was performed at the Yunnan Key Laboratory for Palaeobiology of the Institute of Palaeontology, Yunnan University, China, using a micro-CT (Xradia 520 Versa) with a pixel size of $14.71 \mu \mathrm{m}$ in three axes.

\section{TOOTH MORPHOLOGY AND INTERNAL STRUCTURE}

The general morphology of the dentition of Keichousaurus has been described by Holmes et al. (2008) in their revision of the skull of this taxon. The heterodont teeth with variation of sizes are implanted in deep sockets of the premaxilla and maxilla in the upper jaw and the anterior portion of the dentary in the lower jaw (Figures 2A,B). The teeth in the premaxilla are strongly procumbent (visible in dorsal view) and five in number, larger than the anterior three teeth in the maxilla. The fourth and fifth maxillary teeth are fang-like (caniniform), nearly as large as the largest premaxillary teeth in size (Figures 2A-C), and the sixth and remaining (about 10) maxillary teeth are notably smaller, becoming angled more mesial than labial (Figures 2A,C,D). A nearly complete series of 19 dentary teeth is discernable in the specimen GZU V0028 including 6 enlarged teeth near the symphysis followed by 13 smaller teeth posteriorly.

As typically in other marine reptiles, the tooth of Keichousaurus can be divided into three parts: a crown, a root, and the neck or cervical margin where these two parts 

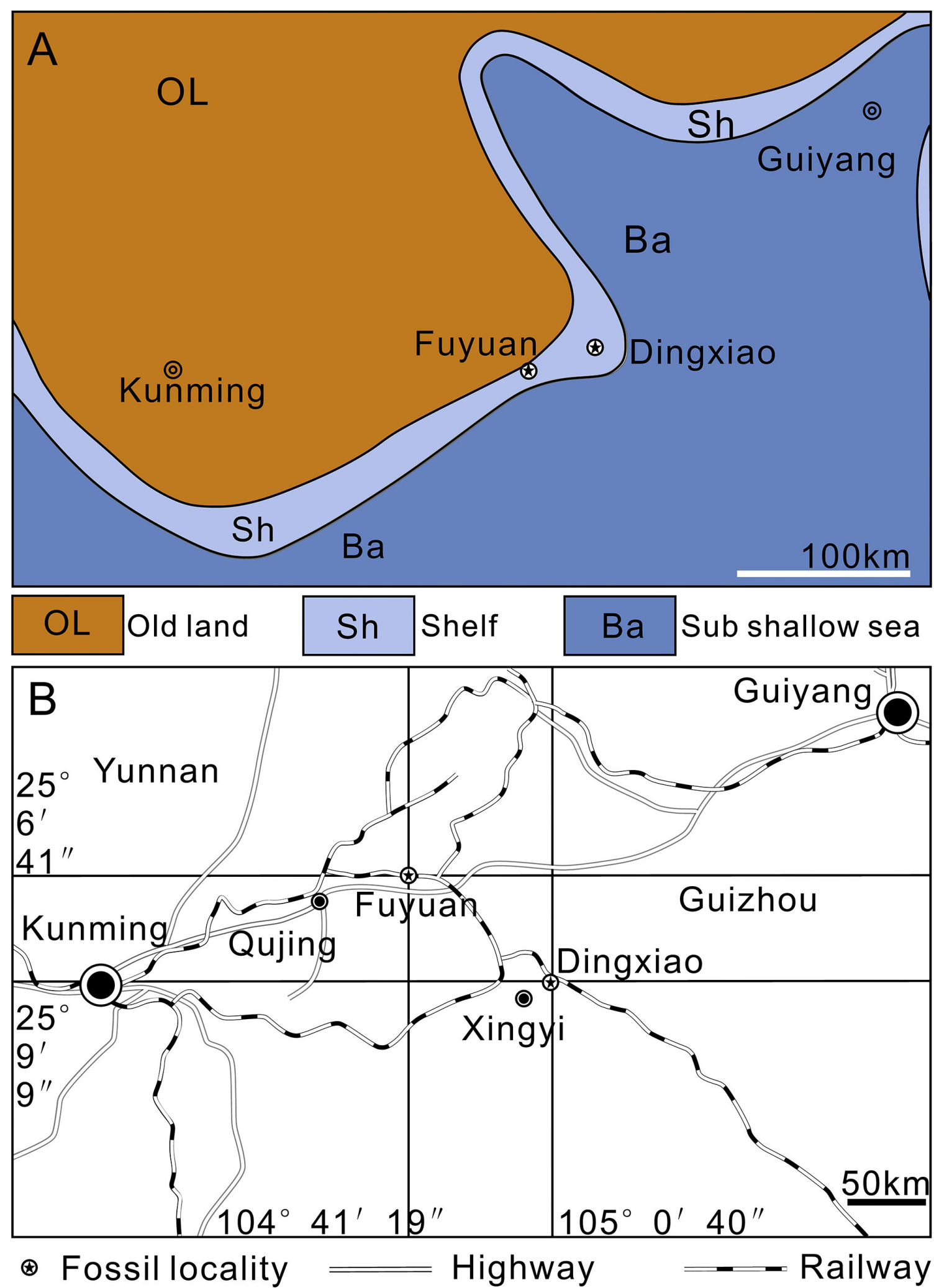


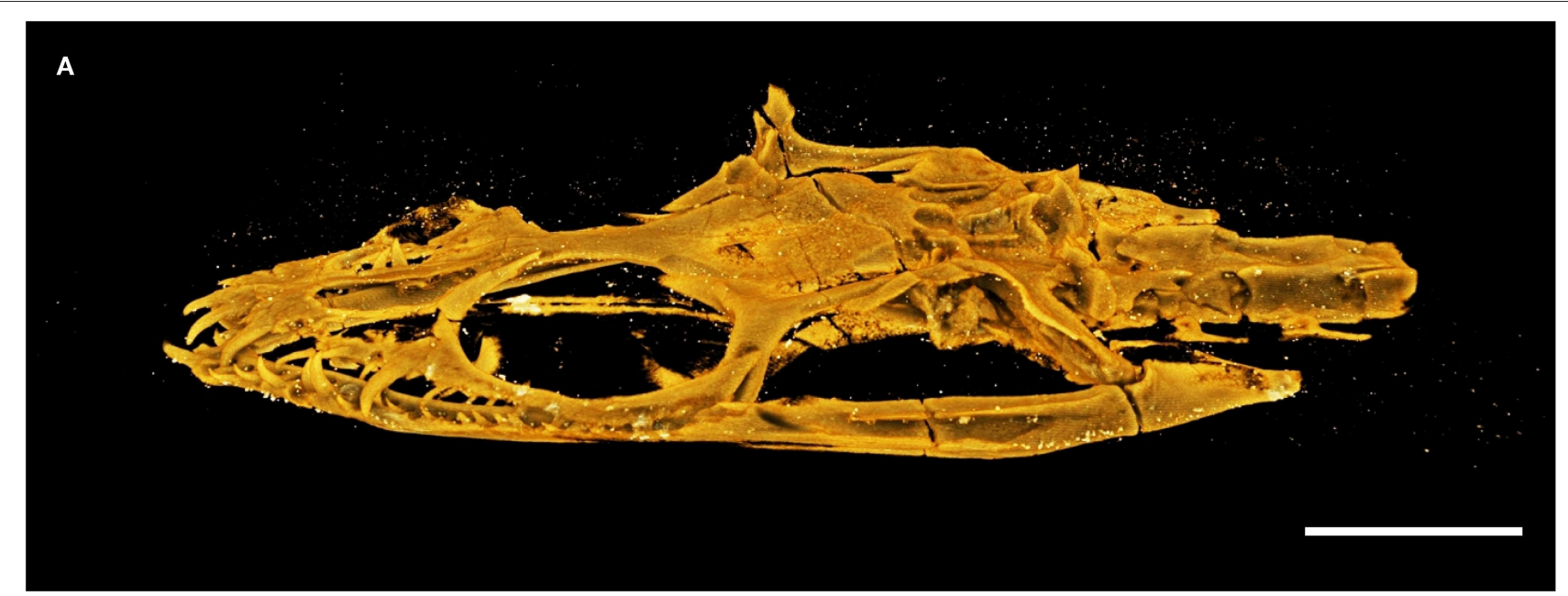

B
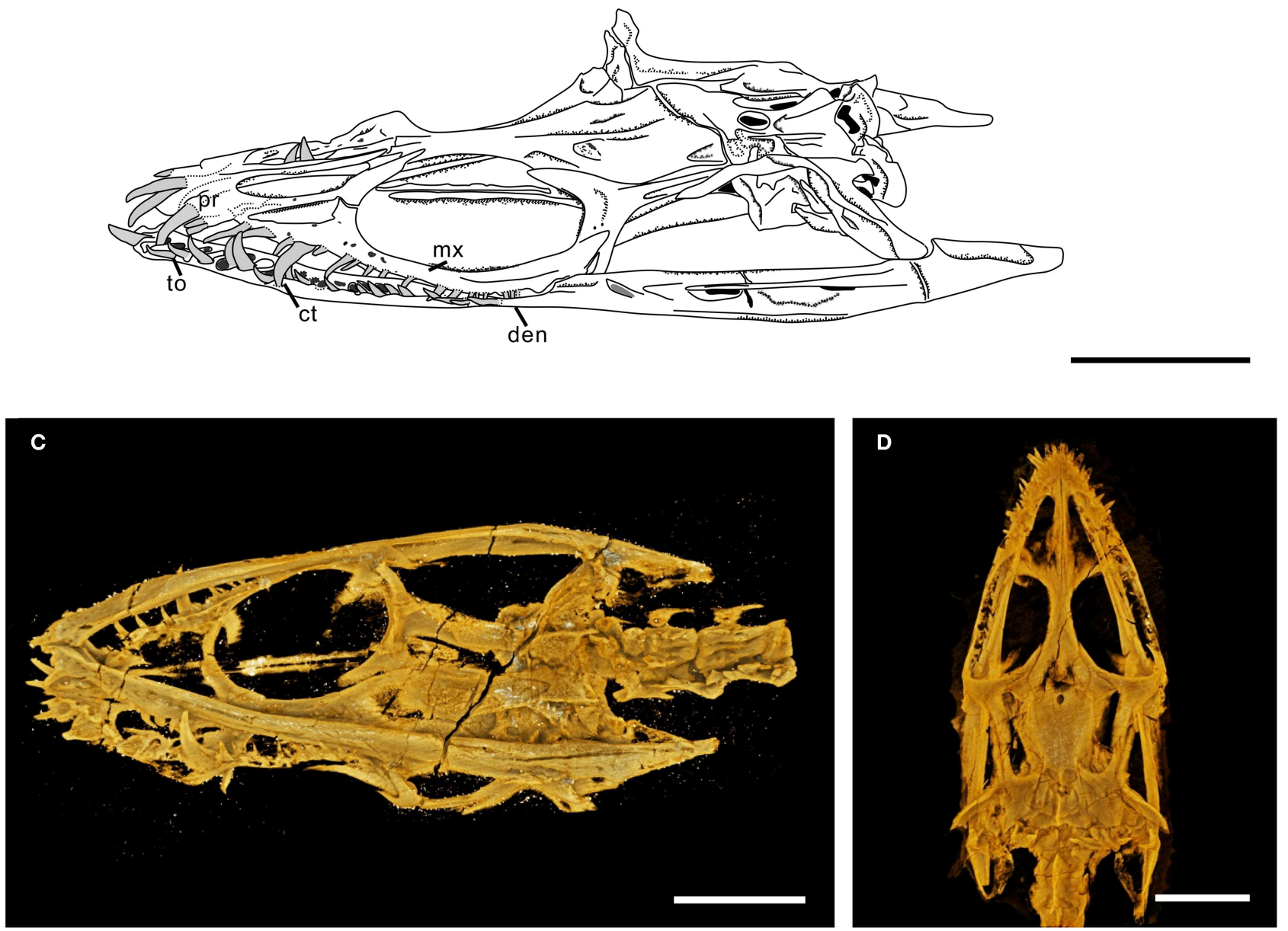

FIGURE 2 | CT scans of skull of Keichousaurus. (A) Dorsolateral view (GZU V0028), scale bars $=5 \mathrm{~mm}$. (B) Line drawing of (A), scale bars $=5 \mathrm{~mm}$. (C) Ventrolateral view (GZU V0028), scale bars $=5 \mathrm{~mm}$. (D) Ventral view (GZU V0516), scale bars $=5 \mathrm{~mm}$. ct, caniniform tooth; den, dentary; mx, maxilla; pr, premaxilla; to, tooth.

meet. The root is invisible in situ, but can be observed when it is detached from the jawbone (Figures 3A,F). It has a contracted basal pedicel deeply intercalated within the concave alveolus
(Figures 3D,E). The nearly cylindrical root gradually shrinks from near the neck toward the opened root apex (Figure 3F). The average length of the root is $0.73 \mathrm{~mm}$, accounting for about half 

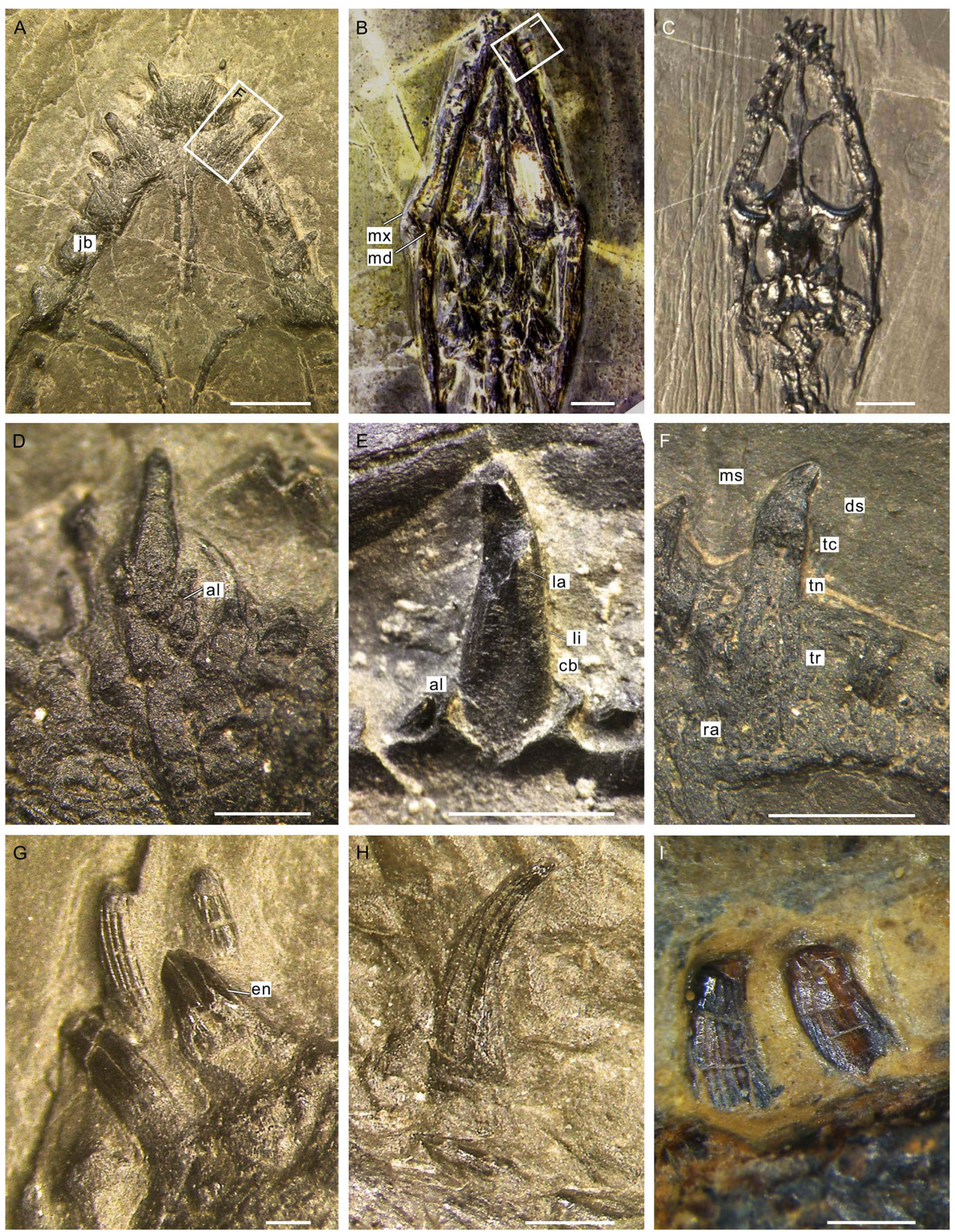

FIGURE 3 | Teeth of Keichousaurus. (A) Premaxillary teeth (GZU V0036), scale bar $=2 \mathrm{~mm}$. (B) Ventral view of the skull (GZU V0095), scale bar $=3 \mathrm{~mm}$. (C) Dorsal view of the skull (GZU V0057), scale bar $=4 \mathrm{~mm}$. (D) Premaxillary tooth, showing the root inserted into a concaved alveolus (GZU V0043), scale bar $=500 \mu \mathrm{m}$. (E) A 
FIGURE 3 | caniniform tooth (GZU V0028), scale bar =1 mm. (F) Magnified view of (A), showing an elongated root, scale bar = $1 \mathrm{~mm}$. (G) Left mandibular anterior teeth (GZU V0023), showing the tooth neck, scale bar $=250 \mu \mathrm{m}$. (H) Right mandibular tooth (GZU V0035), showing the apicobasal ridges, scale bar $=500 \mu \mathrm{m}$. (I) Right mandibular teeth (GZU V0095), showing the transverse furrows, scale bar $=500 \mu \mathrm{m}$. al, alveolus; cb, crown base; ds, distal side; en, enamel; jb, jaw bone; la, labial surface; li, lingual surface; md, mandible; ms, mesial side; mx, maxilla; ra, root apex; tc, tooth crown; tn, tooth neck; tr, tooth root.

to two-thirds of the whole length of the tooth. The waist-shaped neck is presented as an annular depression (Figures 3F,G), having a depth of $0.21-0.34 \mathrm{~mm}$. The crown is conical with a sharp, slightly recurved dental cusp (Figures 3E,F,H). Lingually, it is concave with an arc-shaped mesial surface (Figures $\mathbf{3 G}, \mathbf{H}$ ). The crown has a maximal length of $1.51 \mathrm{~mm}$ in the premaxillary teeth and the ratio of height to width ranges from 2.5 to 3.5 . The external surface of the crown is ornamented with fine, longitudinal ridges separated by multiple regularly spaced grooves (Figures 3G-I). These longitudinal ridges, termed as apicobasal ridges (Young et al., 2012, 2014a,b; Zverkov et al., 2018; McCurry et al., 2019), are straight or slightly curved and unbranched; they extend from the crown base to the apex of cusp, tapering in width along the basal-apical direction. The apicobasal ridges are continuous or interrupted by some shallow, traverse furrows (Figure 3I).

The oval cross-section of the tooth crown (viewed from its basal part) has two dark-colored layers (enamel and dentine layer) surrounding a light-colored pulp cavity (Figures 4A,B,F, 5A,B). A relatively bright and transparent (unevenly mineralized) globular zone is discernable between the enamel and dentine layers (Figures 5A,B). The enamel layer is densely mineralized and very thin (about $5 \mu \mathrm{m}$ ), indicated by a black ring in the tooth section (Figures 5A,B); it gradually becomes sparse toward the neck (Figure 4C). The dentine layer, as the main component of the tooth, is relatively low in density and bears some ridges and cracks in its internal wall (Figures 4A,B). In tooth sections, the annular dentine is simply folded, in which irregular white calcites and centripetally curved, fibril-like dentinal tubules are also present (Figures 5A,C). The circumpulpal dentinal tubules are closely packed near the pulp cavity to make this area darker in color than the surrounding areas of the dentine layer. It appears that some tubules nearly extend into the center of the pulp cavity, indicated by some irregular dark patches in the cavity (Figures 5A,D).

The pulp cavity (including pulp chamber and root canal)

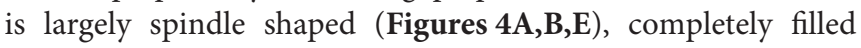
with euhedral crystal grains of white calcites after the internal connective tissue decayed. The average length from the recurved tip of the pulp chamber to the apical portion of the dental cusp (Figures 4A,B,D,E) is $0.36 \mathrm{~mm}$. At the horizontal level of the base of the tooth crown, the pulp cavity reaches its maximum width, which ranges from 0.16 to $0.27 \mathrm{~mm}$ and accounts for about fourth-fifths of the width of the tooth crown.

\section{TOOTH REPLACEMENT}

The tooth replacements of Keichousaurus are traceable in some specimens (GZU V0021, 0044, 0049, 0053), in which small replacement teeth are associated with the pulp cavities of larger predecessor teeth (functional teeth) (Figures 6A-D). Among them, the replacement teeth in the specimens GZU V0049 (Figures 6A,E) and GZU V0021 (Figures 6B,F) are the smallest ones, which are exposed near the mesial-lingual side of the pulp cavities of the predecessor teeth, accounting for slightly less than half of the cavity of predecessor teeth in size. Both have only a loose dentine layer without a distinct enamel layer. In the specimen GZU V0044 (Figures 6C,G), the replacement tooth is larger, accounting for slightly more than half of the pulp cavity of the predecessor tooth. Within the predecessor tooth, the replacement tooth extends anterodorsally from the posteroventral edge of the root to the mesial-labial margin of the pulp cavity. The replacement tooth (GZU V0044) (Figure 6C) bears a triangular pulp cavity larger than that in the replacement tooth of specimens GZU V0021 (Figure 6B). In specimen GZU V0053 (Figures 6D,H), the replacement tooth is the largest one, nearly occupying the whole space of this pulp cavity. The replacement tooth has enamel and dentine layers with an even larger pulp cavity.

Two typical tooth replacement types are present in reptiles (Edmund, 1960; Rieppel, 1978; De Ricqlès and Bolt, 1983): iguanid and varanid tooth replacement types. In the former, a replacement tooth germinates at the lingual surface of root of a functional tooth and then invades into the pulp cavity of its related functional tooth during tooth growth; in the latter, the replacement tooth erupts in the interdental location and does not migrate into the pulp cavity during tooth development. Moreover, there is an intermediate replacement type in some reptiles, in which the replacement tooth adopts the replacement path of the iguanid type (existence of an invasion into the pulp cavity of the functional tooth), but the erupting position is similar to that of replacement tooth in the varanid type, with a distal deviation (Rieppel, 1978; Bertin et al., 2018). Based on the presence of replacement teeth inside the pulp cavity of the functional teeth (Figures 6A-H), we conclude that the tooth replacement of Keichousaurus can largely be referred to the iguanid replacement type. This replacement type was also found in plesiosaurs, Jurassic ichthyosaurs, Platypterygius, and extant crocodilians (Edmund, 1960, 1962; Motani, 1997; Fastnacht, 2008; Maxwell et al., 2012).

\section{TOOTH FUNCTION AND FOOD PREFERENCE}

The teeth of Keichousaurus are thecodont and their roots deeply insert into individual alveoli (Figures 3D,E), such as those of some other eosauropterygians (e.g., Nothosaurus and Simosaurus) and crocodiles (Rieppel, 2001; LeBlanc et al., 2017). The waist-shaped tooth neck has a certain depth $(0.21-0.34 \mathrm{~mm})$ and the interdental gap is likely filled by gums, which contribute 

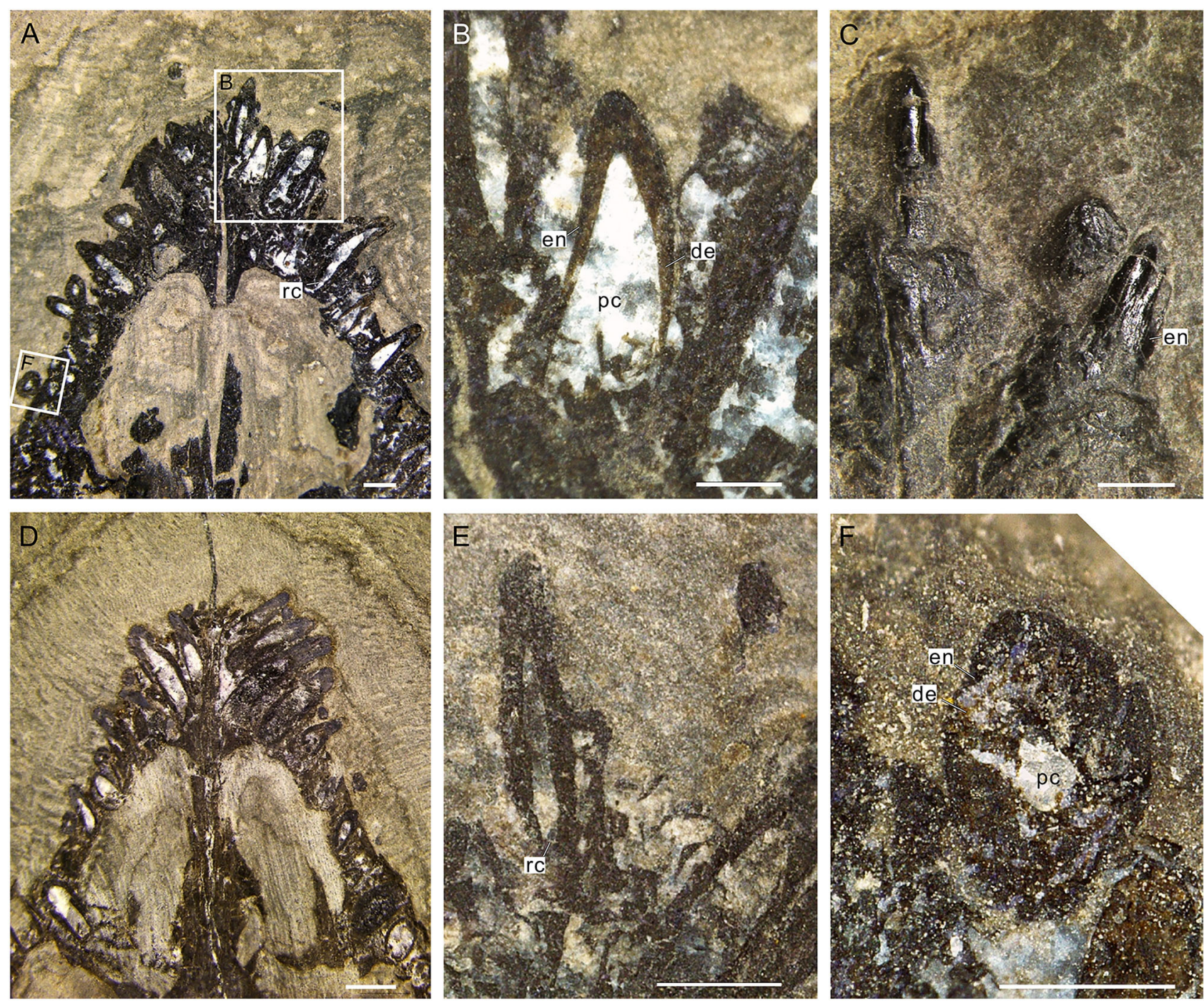

FIGURE 4 | Internal structure of teeth of Keichousaurus. (A) Dorsal view of teeth (GZU V0049), scale bar $=500 \mu \mathrm{m}$. (B) Three right premaxillary teeth, showing the large pulp cavities (GZU V0049), scale bar $=250 \mu \mathrm{m}$. (C) Two teeth of the central premaxilla side, showing the rare faction of enamel on the neck (GZU V0042), scale bar $=500 \mu \mathrm{m}$. (D) Dorsal view (GZU V0050), scale bar = $1 \mathrm{~mm}$. (E) Second teeth on the left premaxilla side (GZU V0046), showing the narrower root canals, scale bar $=500 \mu \mathrm{m}$. (F) Cross-section (GZU V0049), showing a two-layer structure, scale bar = $250 \mu \mathrm{m}$. de, dentine; en, enamel; rc, root canal; pc, pulp cavity.

to the tooth stability (Chung et al., 2006; Carnio et al., 2007; Bourie et al., 2008). The teeth of Keichousaurus in anterior portions of jaws are elongated, fang like, and loosely arranged (Young, 1958, 1965; Jiang, 2002; Holmes et al., 2008; Fu et al., 2013). These teeth might exert the main force used to control prey by latching onto it and preventing escape (Figures $2 \mathrm{~A}, \mathbf{B}, \mathbf{D}$ ). The small teeth in posterior portions of jaws (Figures 2A,C) could act as a ratchet, transporting the prey posteriorly to the esophagus (Taylor, 1987; Taylor and Cruickshank, 1993).

The crowns of Keichousaurus are ornamented with apicobasal ridges (Figures 3G,H). These ridges, also present in other sauropterygians (e.g., Pliosaurus and Helveticosaurus) and some crocodylomorphs (Young et al., 2012, 2014a,b), might help pierce slippery or scaly struggling prey, facilitate blood drain, and prevent the prey from escaping (Frazzetta, 1966; Wright et al.,
1979; Vaeth et al., 1985; Kardong and Young, 1996; Massare, 1997; Young et al., 2014b; McCurry et al., 2019). Plicidentine manifested as apicobasal ridges externally (Figures $\mathbf{3 H}, \mathbf{5 A}, \mathbf{C}$; Tomes, 1878; Maxwell et al., 2012; Macdougall et al., 2014; McCurry et al., 2019) is regarded as a functional property of large predators (Scanlon and Lee, 2002; Modesto and Reisz, 2008). It, commonly seen in labyrinthodonts (Owen, 1841, 1842), mosasaurs (Schultze, 1970), ichthyosaurs (Maxwell et al., 2011), plesiosaurs (Owen, 1841), extant varanoids (Zaher and Rieppel, 1999), and snakes (Scanlon and Lee, 2002), could enhance the stress resistance and strength of the tooth-to-jaw anchoring (Peyer, 1968; Scanlon and Lee, 2002; Maxwell et al., 2011; Macdougall et al., 2014).

Based on the conical crown shape, sharp cusp (Figures 3E,H), moderate size (crown height to width between 2.5 and 3.5), and 

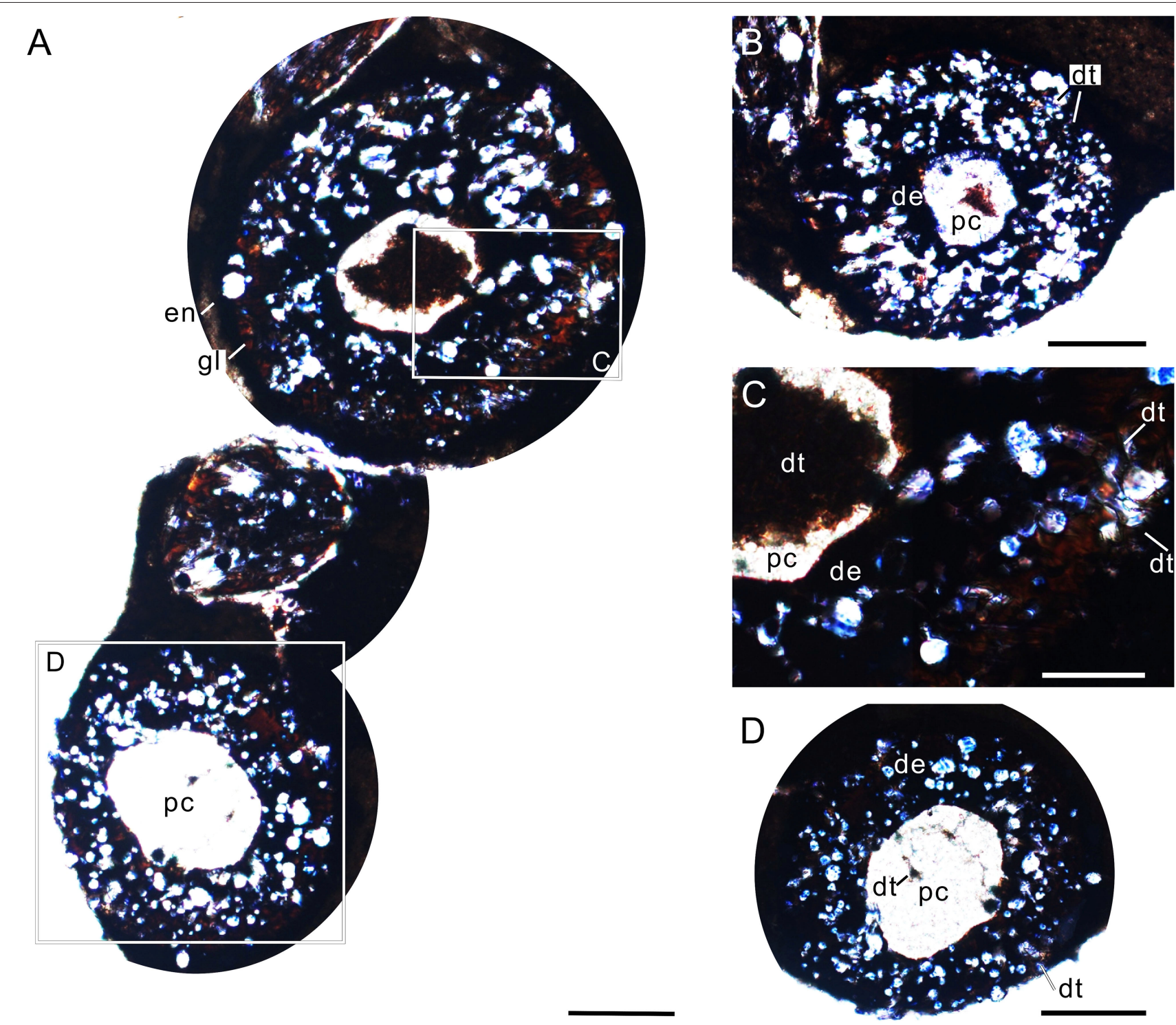

FIGURE 5 | Cross-sectional views of premaxillary teeth of Keichousaurus (GZU V0056). (A) Tooth section (numbers 1 and 2) showing a dense outer ring, globular zone, and a dentinal bending belt, scale bar $=200 \mu \mathrm{m}$. (B) Tooth section (number 3), showing a dense enamel ring and globular zone, scale bar = 100 $\mu \mathrm{m}$. (C) Close-up of (A), showing the dentinal bending belt, with the distribution of firil-like dentinal tubules, scale bar $=50 \mu \mathrm{m}$. (D) Close-up of (A), showing the densely packed dentinal tubules, scale bar $=50 \mu \mathrm{m}$. de, dentine; en, enamel; dt, dentinal tubule; gl, globular zone; pc, pulp cavity.

ornamentation of apicobasal ridges (Figures $\mathbf{3 G}, \mathbf{H}$ ), the teeth of Keichousaurus could be categorized as pierce II (Massare, 1987). This type of piercing teeth (Figures 3A,D,H), unlike those in the filter-feeder Atopodentatus with needle-like teeth (Cheng et al., 2014) or those in durophagous placodontian predators with bulbous teeth (Neenan et al., 2013), are similar to the "fish-trap" teeth of exclusively piscivorous predators such as many mesozoic marine reptiles (ancient plesiosaurs, pliosauroids, teleosaurs, geosaurs, and nothosaurs) and extant river dolphins and gavial (Massare, 1987, 1997; Taylor and Cruickshank, 1993; Sander, 1999; Rieppel, 2002; Ciampaglio et al., 2005; Shang, 2007).
The teeth of Keichousaurus with large pulp cavities (Figures 4A,B,F) might have had sound microcirculation systems and keen sensory nerves to perform well in many respects including eliciting endogenous mechanisms of defense, moderating inflammation, providing pain tolerance, and promoting postinjury healing (Gazelius et al., 1987; Silverman and Kruger, 1987; Kimberly and Byers, 1988; Byers et al., 1990; Olgart, 1990; Taylor and Byers, 1990; Byers and Taylor, 1993; Chen et al., 1994; Walton and Nair, 1995; Evans et al., 1999; Hahn and Liewehr, 2007; Caviedes-Bucheli et al., 2008; Couve et al., 2013; Satoko et al., 2013). The large pulp cavities 


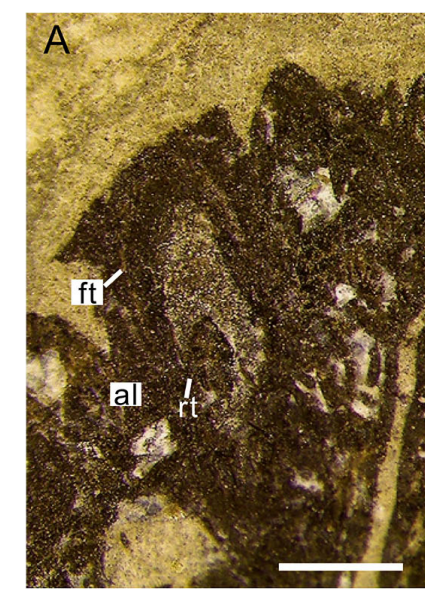

E

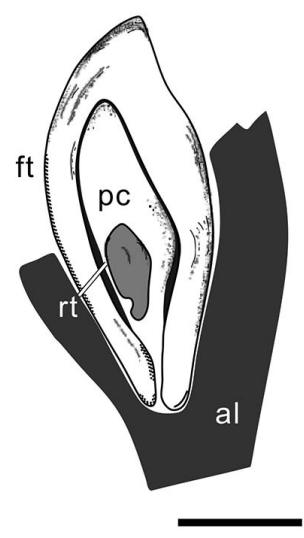

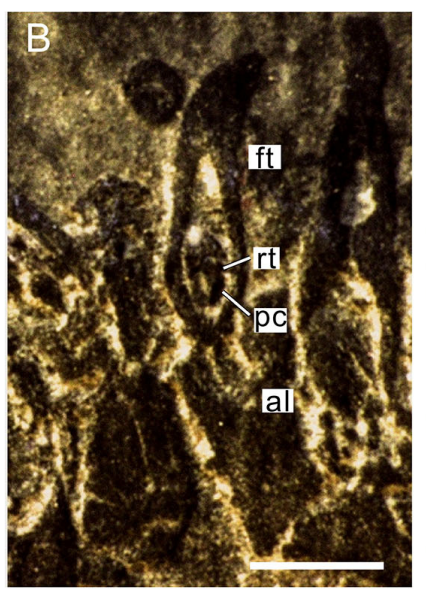

F

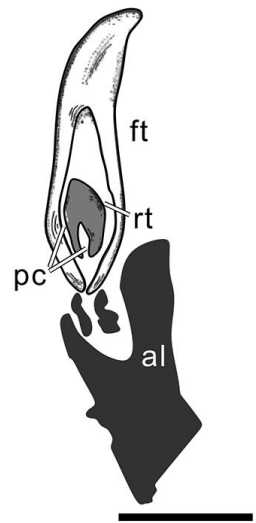

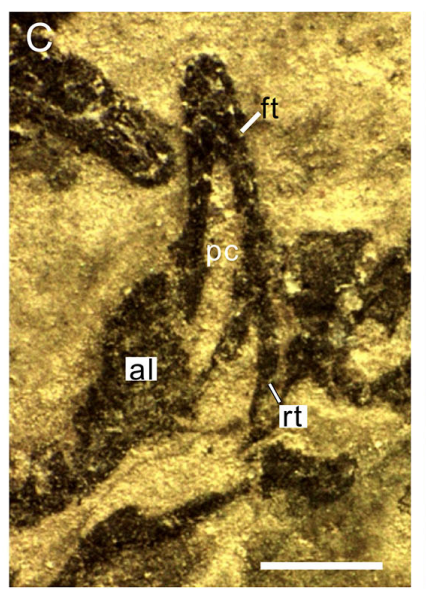

G

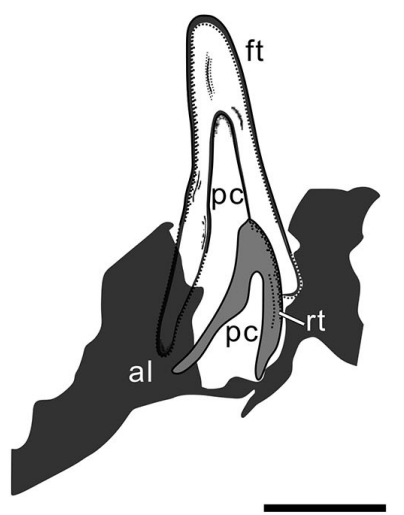

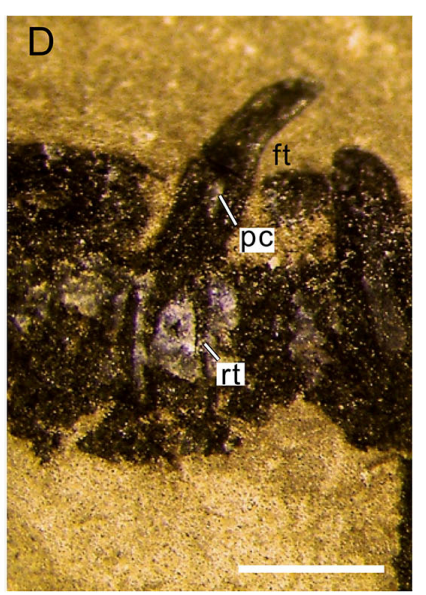

$\mathrm{H}$

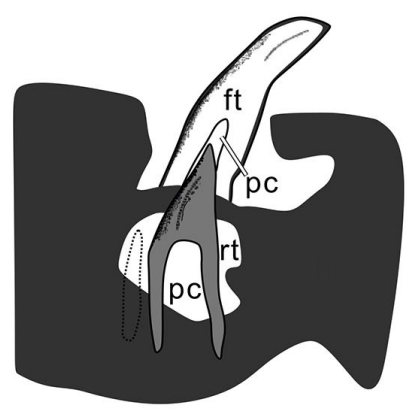

FIGURE 6 | Tooth replacement of Keichousaurus. (A) Left premaxillary teeth in dorsal view (GZU V0049), scale bar = 500 $\mu$ m. (B) Right premaxillary teeth in ventral view (GZU V0021), scale bar $=500 \mu \mathrm{m}$. (C) Left maxillary teeth in dorsal view (GZU V0044), scale bar $=500 \mu \mathrm{m}$. (D) Right maxillary teeth in dorsal view (GZU V0053), showing the, scale bar $=500 \mu \mathrm{m}$. (E) Line drawing of (A), scale bar $=500 \mu \mathrm{m}$. (F) Line drawing of (B), scale bar $=500 \mu \mathrm{m}$. (G) Line drawing of (C), scale bar $=$ $500 \mu \mathrm{m}$. (H) Line drawing of (D), scale bar $=500 \mu \mathrm{m}$. al, alveolus; ft, functional tooth; rt, replacement tooth; pc, pulp cavity.

are prevalent among aquatic carnivores such as dolphins and the crocodilian Alligator (Westergaard and Ferguson, 1990; Slooten, 1991). Considering the large pulp cavity is surrounded by a thin wall, the bending resistance and strength of the tooth might be achieved by the radial foldings of the dentine (Plicidentine) (Figures 5A-C) (Preuschoft et al., 1991). The teeth of Keichousaurus, thus, might respond sensitively to external stimuli and have a relatively strong piercing force.

A rich diversity of small scaly or naked ray-finned fishes has been recovered from the same fossiliferous layer as Keichousaurus including thoracopterids, peltopleurids and luganoiids (Xu et al., 2012, 2015, 2018b; Xu, 2020), holosteans (Liu et al., 2002, 2003; Xu et al., 2018a), and stem teleosts (Tintori et al., 2015). These fishes, as primary consumers in the food web of the Xingyi Biota, appear the potential prey of Keichousaurus and other piscivorous marine reptiles (e.g., nothosaurs). Other primary consumers in the same ecosystem include mysidaceans, gastropods, brachiopods, bivalves, ammonoids, etc. Among them, the small and relatively soft-bodied mysidaceans are probably the alternative prey of
Keichousaurus, but other invertebrates with hard shells are unlikely in the diet of Keichousaurus.

\section{CONCLUSION}

Our detailed examination of well-preserved specimens of Keichousaurus provides new information on its tooth implantation, histology, and replacement. The thecodont teeth of Keichousaurus resemble the "fish-trap" teeth of other extinct and modern piscivorous predators: the cylindrical root deeply inserts into the alveolus with its depth accounting for about a half to two-thirds of the tooth; the dental neck is presented as an annular depression (0.21-0.34 $\mathrm{mm}$ in depth); and the conical, thin-enameled crown bears apicobasal ridges on its surface with a sharp, slightly recurved tooth cusp apically. These ridges might help pierce slippery or struggling scaly prey, facilitate blood drain, and prevent the prey from escaping. In the cross-section of the basal portion of the crown, the tooth has two dark-colored layers (dense enamel and radially folded dentine) surrounding a light-colored large pulp cavity, with some dentinal tubules 
invading the cavity. The tooth replacement of Keichousaurus can largely be referred to the iguanid replacement type on the basis of the invasion of small replacement tooth into the pulp cavity of the predecessor tooth. Deduced from the functional morphology of the tooth, the potential prey of Keichousaurus is mainly composed of small or juvenile fishes and some relatively soft-bodied invertebrates (e.g., mysidacean shrimps) from the same ecosystem.

\section{DATA AVAILABILITY STATEMENT}

The original contributions presented in the study are included in the article/Supplementary Material, further inquiries can be directed to the corresponding authors.

\section{AUTHOR CONTRIBUTIONS}

YW and TL put forward the concept. J-lL wrote this manuscript with comments from G-hX. Y-jQ performed data analysis. JL proposed some suggestions to the article. M-sZ and Y-lL made contributions to data visualization. All authors contributed to the article and approved the submitted version.

\section{REFERENCES}

Benton, M.J., Zhang, Q., Hu, S., Chen, Z. Q., Wen, W., Liu, J., et al. (2013). Exceptional vertebrate biotas from the Triassic of China, and the expansion of marine ecosystems after the Permo-Triassic mass extinction. Earth-Sci. Rev. 125, 199-243. doi: 10.1016/j.earscirev.2014.08.004

Bertin, T. J., Thivichon-Prince, B., LeBlanc, A. R., Caldwell, M. W., and Viriot, L. (2018). Current perspectives on tooth implantation, attachment, and replacement in amniota. Front. Physiol. 9:1630. doi: 10.3389/fphys.2018.01630

Bourie, A., Bissada, N., Al-Zahrani, M. S., Faddoul, F., and Nouneh, I. (2008). Width of keratinized gingiva and the health status of the supporting tissues around dental implants. Int. J. Oral. Maxillofac. Implants. 23, 323-326. doi: 10.1016/j.ijom.2007.09.170

Buchtová, M., Zahradníček, O., Balková, S., and Tucker, A. S. (2013). Odontogenesis in the veiled chameleon (Chamaeleo calyptratus). Arch. Oral. Biol. 58, 118-133. doi: 10.1016/j.archoralbio.2012.10.019

Byers, M. R., and Taylor, P. E. (1993). Effect of sensory denervation on the response of rat molar pulp to exposure injury. J. Dent. Res. 72, 613-618. doi: 10.1177/00220345930720031001

Byers, M. R., Taylor, P. E., Khayat, B. G., and Kimberly, C. L. (1990). Effects of injury and inflammation on pulpal and periapical nerves. J. Endod. 16, 78-84. doi: 10.1016/S0099-2399(06)81568-2

Caldwell, M. W. (2007). Ontogeny, anatomy and attachment of the dentition in Mosasaurs (Mosasauridae: Squamata). Zool. J. Linn. Soc. 149, 687-700. doi: 10.1111/j.1096-3642.2007.00280.x

Carnio, J., Camargo, P. M., and Passanezi, E. (2007). Increasing the apicocoronal dimension of attached gingiva using the modified apically repositioned flap technique: a case series with a 6-month follow-up. J. Periodontol. 78, 1825-1830. doi: 10.1902/jop.2007.060414

Caviedes-Bucheli, J., Muñoz, H. R., Azuero-Holguín, M. M., and Ulate, E. (2008). Neuropeptides in dental pulp: the silent protagonists. J. Endod. 34, 773-788. doi: 10.1016/j.joen.2008.03.010

Chen, X. M., Zhao, H. P., and He, G. H. (1994). Preliminary study on the biological clock of pulp. W. Chin. J. Stomatol. 12, 36-38. (in Chinese with English abstract). doi: 10.CNKI:SUN:HXKQ.0.1994-01-014

Chen, Z. F. (1985). Stratigraphical position of kueichousaurushuiyoung of middletriassic and itssingificance in southwestern guizhou. Guiz. Geol. 2,

\section{FUNDING}

This study was supported by the National Natural Science Foundation of China (Grant No. 41762001), the Guizhou Science and Technology Project (No. 2017-5788), the Strategic Priority Research Program (B) of Chinese Academy of Sciences (Grant No. XDB 26000000), the National Natural Science Foundation of China (No. 41902003), and the Natural Science Foundation of Guizhou (No. 20171057).

\section{ACKNOWLEDGMENTS}

We are grateful to Dr. Qiang Wang (Institute of Vertebrate Paleontology and Paleoanthropology, Chinese Academy of Sciences) for helping in teeth sections, Mr. ShiLong Ye (Fossil Restoration Center, Dingxiao, Guizhou, China) and Mr. Anjing Zhang (Wusha Village of Xingyi, Guizhou, China) for helping in fossil collection and preparation.

\section{SUPPLEMENTARY MATERIAL}

The Supplementary Material for this article can be found online at: https://www.frontiersin.org/articles/10.3389/fevo. 2021.741851/full\#supplementary-material

289-290. (in Chinese with English abstract). Available online at: http://en.cnki. com.cn/Article_en/CJFDTOTAL-GZDZ198503010.htm.

Cheng, L., Chen, X. H., Shang, Q. H., and Wu, X. C. (2014). A new marine reptile from the Triassic of China, with a highly specialized feeding adaptation. Naturwissenschaften. 101, 251-259. doi: 10.1007/s00114-014-1148-4

Cheng, Y. N., Holmes, R., Wu, X. C., and Alfonso, N. (2009). Sexual dimorphism and life History of Keichousaurushui (Reptilia: Sauropterygia). J. Vertebr. Paleontol. 29, 401-408. doi: 10.org/10.1671/039.029.0230

Cheng, Y. N., Wu, X. C., and Ji, Q. (2004). Triassic marine reptiles gave birth to live young. Nature 432, 383-386. doi: 10.1038/nature03050

Chung, D. M., Oh, T. J., Shotwell, J. L., Misch, C. E., and Wang, H. L. (2006). Significance of keratinized mucosa in maintenance of dental implants with different surfaces. J. Periodontol. 7, 1410-1420. doi: 10.1902/jop.2006.050393

Ciampaglio, C. N., Wray, G. A., and Corliss, R. H. (2005). A toothy tale of evolution: convergence in tooth morphology among marine MesozoicCenozoic sharks, reptiles, and mammals. Sediment. Res. 3, 4-7. Available online at: http://www.sites.biology.duke.edu (accessed October, 2020).

Couve, E., Osorio, R., and Schmachtenberg, O. (2013). The amazing odontoblast: activity, autophagy, and aging. J. Dent. Res. 92, 765-772. doi: 10.1177/0022034513495874

De Ricqlès, A., and Bolt, J. R. (1983). Jaw growth and tooth replacement in Captorhinus aguti (Reptilia: Captorhinomorpha): a morphological and histological analysis. J. Vertebr. Paleontol. 3, 7-24. doi: 10.1080/02724634.1983.10011952

Edmund, A. G. (1960). Tooth Replacement Phenomena in the Lower Vertebrates. Toronto: Royal Ontario Museum Toronto, Life Sciences Division Press.

Edmund, A. G. (1962). Sequeuce and Rate of Tooth Replacement in the Crocodilia. Toronto: Royal Ontario Museum Toronto, Life Sciences Division Press.

Evans, D., Reid, J., Strang, R., and Stirrup, D. (1999). A comparison of laser doppler flowmetry with other methods of assessing the vitality of traumatisedanterior teeth. Dent. Traumatol. 15, 284-290. doi: 10.1111/j.1600-9657.1999.tb00789.x

Fastnacht, M. (2008). Tooth replacement pattern of Coloborhynchus robustus (Pterosauria) from the Lower Cretaceous of Brazil. J. Morphol. 269, 332-348. doi: 10.1002/jmor.10591

Frazzetta, T. H. (1966). Studies on the morphology and function of the skull in the Boidae (Serpentes). Part II. Morphology and function of the jaw apparatus in Python sebae and Python molurus. J Morphol. 118, 217-295. 
Fu, W. L., Zhang, X., Ji, C., Jiang, D. Y., Sun, Z. Y., and Hao, W. C. (2013). Morphology of Keichousaurushui from the Middle Triassic of Xingyi, Guizhou Province with comments on its reproduction mode. ActaSci. Natur. Univ. Pekinensis. 49, 102-109. (in Chinese with English abstract). Available online at: http://ir.nigpas.ac.cn/handle/332004/8444

Gazelius, B., Edwall, B., Olgart, L., Lundberg, J. M., Hökfelt, T., and Fischer, J. A. (1987). Vasodilatory effects and coexistence of calcitonin gene-related peptide (CGRP) and substance P in sensory nerves of cat dental pulp. Acta. Physiolo. Scand. 130, 33-40. doi: 10.1111/j.1748-1716.1987.tb08108.x

Geng, B. H, Zhu, M., and Jin, F. (2009). A revision and phylogenetic analysis of Guizhoucoelacanthus (Sarcopterygii, Actinistia) from the Triassic of China. Vertebr. Palasiat. 47, 165-177. doi: 10.1039/b409327e

Hahn, C., and Liewehr, F. R. (2007). Innate immune responses of the dental pulp to caries. J. Endod. 33, 643-651. doi: 10.1016/j.joen.2007.01.001

Handrigan, G. R., and Richman, J. M. (2011). Unicuspid and bicuspid tooth crown formation in squamates. J. Exp. Zool. 316, 598-608. doi: 10.1002/jez.b.21438

Holmes, R., Cheng, Y. N., and Wu, X. C. (2008). New information on the skull of Keichousaurus hui (Reptilia: Sauropterygia) with comments on sauropterygian interrelationships. J. Vertebr. Paleontol. 28, 76-84. doi: 10.1671/0272-4634(2008)2876: NIOTSO2.0.CO;2

Hwang, S. H. (2011). The evolution of dinosaur tooth enamel microstructure. Biol. Rev. 86, 183-216. doi: 10.1111/j.1469-185X.2010.00142.x

Jiang, Z. W. (2002). Discovery and significance of Keichousaurus Fauna in Fuyuan, Yunnan. J. Yunn. Geol. 21, 183-191. (in Chinese with English abstract). doi: 10.3969/j.issn.1004-1885.2002.02.008

Jin, F. (2001). Notes on the discovery of Birgeria in China. Vertebr. Palasiat. 39, 168-176. (in Chinese with English abstract). doi: 10.3969/j.issn.1000-3118.2001.03.002

Kardong, K. V., and Young, B. A. (1996). Dentitional surface features in snakes (Reptilia: Serpentes). Amphibia-Reptilia. 17, 261-276. doi: 10.1163/156853896X00432

Kimberly, C. L., and Byers, M. R. (1988). Inflammation of rat molar pulp and periodontium causes increased calcitonin generelated peptide and axonal sprouting. Anat. Record 222, 289-300. doi: 10.1002/ar.10922 20310

LeBlanc, A. R., Brink, K. S., Cullen, T. M., and Reisz, R. R. (2017). Evolutionary implications of tooth attachment versus tooth implantation: a case study using dinosaur, crocodilian, and mammal teeth. J. Vertebr. Paleontol. 37:e1354006. doi: 10.1080/02724634.2017.1354006

LeBlanc, A. R., and Reisz, R. R. (2015). Patterns of tooth development and replacement in captorhinid reptiles: a comparative approach for understanding the origin of multiple tooth rows. J. Vertebr. Paleontol. 35:e919928. doi: 10.1080/02724634.2014.919928

Li, J. L. (2006). A brief summary of the Triassic marine reptiles of China. Vertebr. Palasiat. 44, 99-108. doi: 10.3969/j.issn.1000-3118.2006.01.006

Li, Q., and Liu, J. (2020). An Early Triassic sauropterygian and associated fauna from South China provide insights into Triassic ecosystem health. Commun. Biol. 3:63. doi: 10.1038/s42003-020-0778-7

Li, Z. G, Sun, Z. Y., Jiang, D. Y., and Ji, C. (2016). LA-ICP-MS Zircon U-Pb age of the fossil layer of Triassic Xingyi Fauna from Xingyi, Guizhou, and its significance. Geol. Rev. 62, 779-790. (in Chinese with English abstract). doi: 10. 16509/j.georeview.2016.03.018

Lin, K., and Rieppel, O. (1998). Functional morphology and ontogeny of Keichousaurus hui (Reptilia, Sauropterygia). Fieldiana. Geol. 39, 1-35.

Lin, W. B., Jiang, D. Y., Rieppel, O., Motani, R., Tintori, A., Sun, Z. Y., et al. (2021). Panzhousaurus rotundirostris Jiang et al., 2019 (Diapsida: Sauropterygia) and the recovery of the monophyly of Pachypleurosauridae. J. Vertebr. Paleontol. 41:e1901730. doi: 10.1080/02724634.2021.1901730

Liu, B. J., and Xu, X. S. (1994). Atlas of the Lithofacies and Palaeogeography of South China (Sinian-Triassic). Shanghai: Science Press.

Liu, G. B., Yin, G. Z., and Wang, X. H. (2002). On the most primitive amid fish from Upper Triassic of Xingyi, Guizhou. Acta. Palaeontolo. Sin. 41, 461-463. (in Chinese with English abstract). doi: 10.3969/j.issn.0001-6616.2002. 03.015

Liu, G. B., Yin, G. Z., Wang, X. H., Luo, Y. M., and Wang, S. Y. (2003). New discovered fishes from Keichousaurus bearing horizon of Late Triassic in Xingyi of Guizhou. Acta. Palaeontolo. Sin. 42, 346-366. (in Chinese with English abstract). doi: 10.CNKI:SUN:GSWX.0.2003-03-003
Macdougall, M.J., LeBlanc, A. R., and Reisz, R.R. (2014). Plicidentine in the Early Permian parareptile Colobomycter pholeter, and its phylogenetic and functional significance among coeval members of the clade. PLOS ONE 9:e96559. doi: 10.1371/journal.pone.0096559

Maisch, M. W., and Matzke, A. T. (1997). Observations on Triassic Ichthyosaurs. Part I. structure of the palate and mode of tooth implantation in Mixosaurus Cornalianus (bassani, 1886). Neues. Jahrb. Geol. P-M. 12, 717-732. doi: 10.1127/njgpm/1997/1997/717

Massare, J. A. (1987). Tooth morphology and prey preference of Mesozoic marine reptiles. J. Vertebr. Paleontol. 7, 121-137. doi: 10.1080/02724634.1987. 10011647

Massare, J. A. (1997). "Faunas, behavior, and evolution," in Ancient Marine Reptiles, ed. J. M. Callaway, and E. L. Nicholls (London, UK, and San Diego, USA: ACAD Press), 403-410.

Maxwell, E. E., Caldwell, M. W., and Lamoureux, D. O. (2012). Tooth histology, attachment, and replacement in the Ichthyopterygia reviewed in an evolutionary context. Paläeontolo. Z. 86, 1-14. doi: 10.1007/s12542-011-0115-Z

Maxwell, E. E., Caldwell, M. W., Lamoureux, D. O., and Budney, L. A. (2011). Histology of tooth attachment tissues and plicidentine in Varanus (Reptilia: Squamata), and a discussion of the evolution of amniote tooth attachment. $J$. Morphol. 272, 1170-1181. doi: 10.1002/jmor.10972

McCurry, M. R., Evans, A. R., Fitzgerald, E. M., McHenry, C. R., Bevitt, J., and Pyenson, N. D. (2019). The repeated evolution of dental apicobasal ridges in aquatic-feeding mammals and reptiles. Biol. J. Linn. Soc. 127, 245-259. doi: 10.1093/biolinnean/blz025

Mehler, S. J., and Bennett, R. A. (2003). Oral, dental, and beak disorders of reptiles. Vet. Clin. Exot. Pract. 6, 477-503. doi: 10.1016/S1094-9194(03)00032-X

Modesto, S. P., and Reisz, R. R. (2008). New material of Colobomycter pholeter, a small parareptile from the lower permian of oklahoma. J. Vertebr. Paleontol. 28, 677-684. doi: 10.1671/0272-4634(2008)28677:NMOCPA2.0.CO;2

Motani, R. (1997). "Temporal and spatial distribution of tooth implantations in Ichthyosaurs," in Ancient Marine Reptiles, ed. J. M. Calloway, and E. L. Nicholls (London, UK, and San Diego, USA: ACAD Press), 81-103. doi: 10.1016/B978-012155210-7/50007-7

Motani, R., Jiang, D. Y., Rieppel, O., Xue, Y. F., and Tintori, A. (2015). Adult sex ratio, sexual dimorphism and sexual selection in a Mesozoic reptile. Proc. $R$. Soc. B-Biol. Sci. 282:1658. doi: 10.1098/rspb.2015. 1658

Neenan, J. M., Klein, N., and Scheyer, T. M. (2013). European origin of placodont marine reptiles and the evolution of crushing dentition in placodontia. Nat. Commun. 4:1621. doi: 10.1038/ncomms2633

Neenan, J. M., Li, C., Rieppel, O., Bernardini, F., Tuniz, C., Muscio, G., et al. (2014). Unique method of tooth replacement in durophagous placodont marine reptiles, with new data on the dentition of Chinese taxa. J. Anat. 224, 603-613. doi: 10.1111 /joa.12162

Ni, P. G., Tintori, A., Sun, Z. Y., and Jiang, D. Y. (2017). A new specimen of Birgeria liui (Osteichthyes, Actinopterygii) from the Longobardian (Ladinian, Middle Triassic) of Xingyi, Guizhou Province, South China. Research 3, 55-58. doi: $10.14456 /$ randk.2017.27

Olgart, L. M. (1990). "Functions of peptidergic nerves," in Dynamic Aspects of Dental Pulp, ed. R. Inoki, T. Kudo, and L. M. Olgart (Dordrecht, NL: Springer Press), 349-362.

Owen, R. (1841). XXXI.-On the teeth of species of the genus Labyrinthodon (Mastodonsaurus of jaeger) common to the German keuper formation and the Lower sandstone of Warwick and Leamington. Trans. Geol. Soc. Lond. 5, 503-513.

Owen, R. (1842). XXXII.-Description of parts of the Skeleton and Teeth of five species of the Genus Labyrinthodon (Lab. leptognathus, Lab. pachygnathus, and Lab. ventricosus, from the Coton-end and Cubbington Quarries of the Lower Warwick Sandstone; Lab. Jægeri, from Guy's Cliff, Warwick; and Lab. scutulatus, from Leamington); with remarks on the probable identity of the Cheirotherium with this genus of extinct Batrachians. Trans. Geol. Soc. Lond. 2, 515-543. Available online at: http://trn.lyellcollection.org/ at Dalhousie University (accessed June 24, 2015).

Peyer, B. (1968). Comparative Odontology. Chicago: Univeristy of Chicago Press.

Preuschoft, H., Reif, W. E., Loitsch, C., and Tepe, E. (1991). "The function of labyrinthodont teeth: big teeth in small jaws," in Constructional morphology and evolution, ed. N. Schmidt-Kittler and K. Vogel (Bln-Heidelb, De: Springer), 151-171. doi: 10.1007/978-3-642-76156-0_12 
Radinsky, L. (1961). Tooth histology as a taxonomic criterion for cartilaginous fishes. J. Morphol 109, 73-92. doi: 10.1002/jmor.1051090106

Rieppel, O. (1978). Tooth replacement in anguinomorph lizards. Zoomorphologie 91, 77-90. doi: 10.1007/BF00994155

Rieppel, O. (1999). Phylogeny and paleobiogeography of Triassic Sauropterygia: problems solved and unresolved. Palaeogeogr. Palaeocl. 153, 1-15. doi: 10.1016/S0031-0182(99)00067-X

Rieppel, O. (2001). Tooth implantation and replacement in Sauropterygia. Palaeontol. Z. 75, 207-217. doi: 10.1007/BF02988014

Rieppel, O. (2002). Feeding mechanics in Triassic stem-group sauropterygians: the anatomy of a successful invasion of Mesozoic seas. Zool. J. Linn. Soc. 135, 33-63. doi: 10.1046/j.1096-3642.2002.00019.x

Rieppel, O., and Lin, K. (1995). Pachypleurosaurs (Reptilia: Sauropterygia) from the lower Muschelkalk, and a review of the Pachypleurosauroidea. Fieldiana. Geol. 32, 1-44.

Rieppel, O., Liu, J., and Bucher, H. (2000). The first record of a thalattosaur reptile from the Late Triassic of southern China (Guizhou Province, PR China). J. Vertebr. Paleontol. 20, 507-514. doi: 10.1671/0272-4634(2000)0200507:TFROAT2.0.CO;2

Rücklin, M., Donoghue, P., Johanson, Z., Trinajstic, K., Marone, F., and Stampanoni,. M. (2012). Development of teeth and jaws in the earliest jawed vertebrates. Nature 491, 748-751. doi: 10.1038/nature11555

Sander, P. M. (1999). The microstructure of reptilian tooth enamel: terminology, function, and phylogeny. Münch. Geow. Abhandl. A. Geologie. Palae. 38, 87-97

Sassoon, J., Foffa, D., and Marek, R. (2015). Dental ontogeny and replacement in Pliosauridae. R. Soc. Open Sci. 2:150384. doi: 10.1098/rsos. 150384

Satoko, K., Shinya, K., Azusa, Y., Zenzo, M., Yuzo, T., and Yuji, M. (2013). Optical measurement of blood oxygen saturation of dental pulp. Biomed. Eng. 2013, 1-6. doi: $10.1155 / 2013 / 502869$

Scanlon, J. D., and Lee, M. S. (2002). Varanoid-like dentition in primitive snakes (Madtsoiidae). J. Herpetol. 36, 100-106.

Schultze, H. P. (1970). Folded teeth and the monophyletic origin of tetrapods. Am. Mus. Nat. Hist. 2408, 1-10.

Shang, Q. H. (2007). New information on the dentition and tooth replacement of nothosaurus (reptilia: sauropterygia). Palaeoworld. 16, 254-263. doi: 10.1016/j.palwor.2007.05.007

Shang, Q. H., Wu, X. C., and Li, C. (2020). A New Ladinian Nothosauroid (Sauropterygia) from Fuyuan, Yunnan Province, China. J.Vertebr. Paleontol. 40:e1789651. doi: 10.1080/02724634.2020.1789651

Silverman, J. D., and Kruger, L. (1987). An interpretation of dental innervation based upon the pattern of calcitonin gene-related peptide (cgrp)-immunoreactive thin sensory axons. Somatosens. Res. 5, 157-175. doi: $10.3109 / 07367228709144624$

Slooten, E. (1991). Age, growth, and reproduction in Hector's dolphins. Can. J. Zool. 69, 1689-1700. doi: 10.1139/Z91-234

$\mathrm{Su}$, D. Z. (1959). Triassic fishes from Kueichow, Southwest China. Vertebr. Palasiat. 3, 205-210. (in Chinese with English abstract). doi: 10.CNKI:SUN:GJZD.0.1959-04-006

Sun, Z. Y., Jiang, D.Y., Ji, C., and Hao, W. C. (2016). Integrated biochronology for Triassic marine vertebrate faunas of Guizhou Province, South China. J. Asian. Earth. Sci. 118, 101-110. doi: 10.1016/j.jseaes.2016.01.004

Taylor, M. A. (1987). How tetrapods feed in water: a functional analysis by paradigm. Zool. J. Linn. Soc 91, 171-195. doi: 10.1111/j.1096-3642.1987.tb01727.x

Taylor, M. A., and Cruickshank, A. R. I. (1993). Cranial anatomy and functional morphology of Pliosaurus brachyspondylus (Reptilia: Plesiosauria) from the Upper Jurassic of Westbury, Wiltshire. Philos. T. R. Soc. B. 341, 399-418. Available online at: http://www.jstor.org/page/info/about/policies/terms.jsp (accessed May, 2021).

Taylor, P. E., and Byers, M. R. (1990). An immunocytochemical study of the morphological reaction of nerves containing calcitonin gene-related peptide to microabscess formation and healing in rat molars. Arch. Oral. Biol. 35, 629-638. doi: 10.1016/0003-9969(90)90029-A

Tintori, A., Sun, Z. Y, Ni, P. G., Lombardo, C., Jiang, D.Y., and Ryosuke, M. (2015). Oldest stem Teleostei from the late Ladinian (Middle Triassic) of southern China. Riv. Ital. Paleontolo. Stratigrafia 121, 285-296. doi: 10.13130/2039-4942/651
Tomes, C. S. (1878). II. On the structure and development of vascular dentine. Proc. R. Soc. Lond. 169, 25-47. doi: 10.1098/rstl.1878.0003

Ungar, P. (2010). Mammal Teeth: Origin, Evolution and Diversity. Baltimore: Johns Hopkins University Press.

Vaeth, R. H., Rossman, D. A., and Shoop, W. (1985). Observations of tooth surface morphology in snakes. J. Herpetol. 19, 20-26. doi: 10.2307/1564416

Walton, R. E., and Nair, P. N. R. (1995). Neural elements in dental pulp and dentin. OralRadiol. Endodontol. 80, 710-719. doi: 10.1016/S1079-2104(05)80256-2

Wang, C. Y., Kang, P. Q., and Wang, Z. H. (1998). Conodont based age of the Keichousaurus hui Yang, 1958. Acta. Micropalaeontol. Sin. 15, 196-198. (in Chinese with English abstract). doi: 10.1088/0256-307X/15/12/010

Wang, L. T. (2002). Study advances on triassic marine reptiles in guizhou. Guiz. Geol. 19, 6-9. (in Chinese with English abstract). doi: 10.3969/j.issn.1000-5943. 2002.01.002

Wang,. L. T. (1996). A discussion on horizon and age of Keichousaurus hui occurrence. Guizh. Geol. 3, 209-216. (in Chinese with English abstract). doi: 10.GZUVDZ.0.1996-03-002

Westergaard, B., and Ferguson, M. W. (1990). Development of the dentition in Alligator mississippiensis: upper jaw dental and craniofacial development in embryos, hatchlings, and young juveniles, with a comparison to lower jaw development. Am. J. Anat. 187, 393-421. doi: 10.1002/aja.1001870407

Wright, D. L., Kardong, K. V., and Bentley, D. L. (1979). The functional anatomy of the teeth of the western terrestrial garter snake, Thamnophis elegans. Herpetologica 35, 223-228. Available online at: http://www.jstor.org/stable/ 3891690

Xu, G. H. (2020). A new species of Luganoia (Luganoiidae, Neopterygii) from the Middle Triassic Xingyi Biota, Guizhou, China. Vert. Palasiat. 58, 267-282. doi: 10.19615/j.cnki.1000-3118.200624

Xu, G. H., Ma, X.Y., and Ren, Y. (2018a). Fuyuanichthys wangi gen. et sp. nov. from the Middle Triassic (Ladinian) of China highlights the early diversification of ginglymodian fishes. PeerJ 6:e6054. doi: 10.7717/peerj.6054

Xu, G. H., Ma, X.Y., and Zhao, L. J. (2018b). A large peltopleurid fish (Actinopterygii: Peltopleuriformes) from the Middle Triassic of Yunnan and Guizhou, China. Vert. Palasiat 56, 106-120. doi: 10.19615/j.cnki.1000-3118.171225

$\mathrm{Xu}, \mathrm{G}$. H., and Ma, X. Y. (2018). Redescription and phylogenetic reassessment of Asialepidotus shingyiensis (Holostei: Halecomorphi) from the Middle Triassic (Ladinian) of China. Zool. J. Linn. Soc. 184, 95-114. doi: 10.1093/zoolinnean/zlx105

Xu, G. H., Zhao, L. J., Gao, K. Q., and Wu, F. X. (2012). A new stemneopterygian fish from the Middle Triassic of China shows the earliest over-water gliding strategy of the vertebrates. Proc. R. Soc. B-Biol. Sci. 280:20122261. doi: 10.1098/rspb.2012.2261

Xu, G. H., Zhao, L. J., and Shen, C. C. (2015). A Middle Triassic thoracopterid from China highlights the evolutionary origin of over-water gliding in early ray-finned fishes. Biol. Lett. 11:20140960. doi: 10.1098/rsbl.2014.0960

Xue, Y. F., Jiang, D. Y., Motani, R., Rieppel, O., Sun, Y. L., Sun, Z. Y., et al. (2013). New information on sexual dimorphism and allometric growth in Keichousaurus hui, a pachypleurosaur from the middle triassic of Guizhou, South China. Acta. Palaeontol. Pol. 60, 681-687. doi: 10.4202/app.00006.2013

Yang, S. R., Liu, J., and Zhang, M. F. (1995). Conodonts of the Falang Formation of southwestern Guizhou and their age. J. Stratigra. 19, 161-170. (in Chinese with English abstract). Available online at: http://www.cnki.com.cn/Article/ CJFDTotal-DCXZ503.000.htm (accessed August, 2020).

Young, C. C. (1958). On the new Pachypleurosauroidea from Keichow, southwest China. Ver. PalAsiat. 2, 69-82.

Young, C. C. (1965). On the new nothosaurs from Hupeh and Kweichou. China. Ver. PalAsiat. 9, 315-356. doi: 10.1111/j.1745-7254.2008.00827.x

Young, M. T., Brusatte, S. L., De Andrade, M. B., Desojo, J. B., Beatty, B. L., Steel, L., et al. (2012). The cranial osteology and feeding ecology of the metriorhynchid crocodylomorph genera Dakosaurus and Plesiosuchus from the Late Jurassic of Europe. PLoS ONE 7:e44985. doi: 10.1371/journal.pone.004 4985

Young, M. T., De Andrade, M. B., Cornée, J. J., Steel, L., and Foffa, D. (2014a). April. Re-description of a putative Early Cretaceous "teleosaurid" from France, with implications for the survival of metriorhynchids and teleosaurids across the Jurassic-Cretaceous Boundary. Ann. Paléontol. 100, 165-174. doi: 10.1016/j.annpal.2014.01.002 
Young, M. T., Steel, L., Brusatte, S. L., Foffa, D., and Lepage, Y. (2014b). Tooth serration morphologies in the genus Machimosaurus (Crocodylomorpha, Thalattosuchia) from the Late Jurassic of Europe. Roy. Soc. Open. Sci. 1:140269. doi: 10.1098/rsos. 140269

Zaher, H., and Rieppel, O. (1999). Tooth Implantation and Replacement in Squamates, with Special Reference to Mosasaur Lizards and Snakes. New York: American museum of nature history Press.

Zou, X., Balini, M., Jiang, D.Y., Tintori, A., Sun, Z. Y., and Sun, Y. L. (2015). Ammonoids from the Zhuganpo Member of the Falang Formation at Nimaigu and their relevance for dating the Xingyi fossil-lagerstätte (late Ladinian, Guizhou, China). Riv. Ital. Paleontol. S. 2, 135-161. doi: 10.13130/2039-4942/6511

Zverkov, N. G., Fischer, V., Madzia, D., and Benson, R. B. (2018). Increased pliosaurid dental disparity across the JurassicCretaceous transition. Palaeontology. 61, 825-846. doi: 10.1111/pala. 12367
Conflict of Interest: The authors declare that the research was conducted in the absence of any commercial or financial relationships that could be construed as a potential conflict of interest.

Publisher's Note: All claims expressed in this article are solely those of the authors and do not necessarily represent those of their affiliated organizations, or those of the publisher, the editors and the reviewers. Any product that may be evaluated in this article, or claim that may be made by its manufacturer, is not guaranteed or endorsed by the publisher.

Copyright (C) 2021 Liao, Lan, Xu, Li, Qin, Zhao, Li and Wang. This is an open-access article distributed under the terms of the Creative Commons Attribution License (CC $B Y)$. The use, distribution or reproduction in other forums is permitted, provided the original author(s) and the copyright owner(s) are credited and that the original publication in this journal is cited, in accordance with accepted academic practice. No use, distribution or reproduction is permitted which does not comply with these terms. 